\title{
Sources of Resistance to Downy Mildew in Wild and Weedy Sorghums
}

\author{
V. Kamala, S. D. Singh, P. J. Bramel,* and D. Manohar Rao
}

\begin{abstract}
Sorghum downy mildew (SDM), caused by Peronosclerospora sorghi Weston and Uppal (Shaw), is a serious disease of sorghum [Sorghum bicolor (L.) Moench] and maize (Zea mays L.). The wild relatives of sorghum, both cross compatible and cross incompatible with S. bicolor, could provide alternate sources of resistance genes for the long-term control of SDM. The objective of this study was to assess the downy mildew reaction of several taxa of wild and weedy sorghums. One hundred three wild and weedy sorghums, and six cultivated types belonging to five sections, representing 17 species, originating from Asia, Australia, Africa, and the USA, were greenhouse tested for downy mildew resistance during the rainy seasons of 1998 and 1999 at ICRISAT, Patancheru, India. Forty-five accessions comprising 15 species from four sections, parasorghum, heterosorghum (S. laxiflorum Bailey), chaetosorghum (S. macrospermum Garber), and stiposorghum (S. angustum S. T. Blake, S. ecarinatum Lazarides, S. extans Lazarides, $S$. intrans F. Muell. ex Benth., $S$. interjectum Lazarides, S. stipoideum (Ewart \& Jean White) C. Gardener \& C. E. Hubb.), including all accessions from Australia, exhibited immunity to downy mildew. Cultivated types and wild races of section Sorghum showed the greatest susceptibility (mean downy mildew infection of 62 and $46 \%$, respectively), while accessions of S. halepense (L.) Pers. were comparatively less susceptible $(36 \%$ mean downy mildew infection). Potential new sources of resistance genes from wild and weedy sorghums were identified that could be used to develop resistant cultivars to control downy mildew.
\end{abstract}

$\mathrm{S}^{\mathrm{o}}$ RGHUM DOWNY MILDEW is a serious disease of sorghum and maize and causes heavy losses in grain yield in many parts of the semi arid tropics where sorghum is a staple for human and animal consumption. The disease is of quarantine significance because of its seed-borne nature. A number of sources of resistance have been identified and successfully used to produce disease resistant cultivars (Frederiksen et al., 1973, Henzell et al., 1982, Shivana and Anahosur, 1990). However, the breakdown of resistance due to the development and spread of more virulent races of the pathogen associated with the repeated cultivation of resistant cultivars underscores the need to develop cultivars with broadbased resistance utilizing genes from diverse sources (Craig and Odvody, 1992).

Wild species have contributed novel resistance genes to the improvement of cereals such as rice (Oryza sativa L.), wheat (Triticum aestivum L.), and barley (Hordeum vulgare L) (Goodman et al., 1987). The wild relatives of sorghum, both cross compatible and cross incompatible with S. bicolor, could provide alternate sources of resis-

V. Kamala, National Bureau of Plant Genetic Resources, Regional Station, Rajendranagar, Hyderabad 500 030, Andhra Pradesh, India; S.D. Singh and P.J. Bramel, Genetic Resources and Enhancement Programme, ICRISAT, Patancheru 502 324, Andhra Pradesh, India; D. Manohar Rao, Dep. of Genetics, Osmania Univ., Hyderabad 500 007, Andhra Pradesh, India. Received 9 July 2001. *Corresponding author (P.Bramel@CGIAR.ORG).

Published in Crop Sci. 42:1357-1360 (2002). tance genes for the long-term control of SDM. The objective of this study was to assess the downy mildew reaction of several taxa of wild and weedy sorghums.

\section{MATERIALS AND METHODS}

One hundred nine sorghum accessions, belonging to 17 species including five accessions of an unknown species, representing five sections, were screened for their reaction to SDM. Species of sections chaetosorghum, heterosorghum, and stiposorghum were represented by 19 accessions exclusively from Australia. Section parasorghum was represented by 28 accessions belonging to five species from Australia [S. australiense Garber and Snyder, S. brevicallosum Garber, S. timorense (Kunth) Buse, S. nitidum (Vahl) Pers. and S. matarankense Garber and Snyder], one species from Africa (S. versicolor Anderss.), and one species from Africa and Asia [S. purpureosericeum (Hochst. Ex A. Rich.)]. Section sorghum was represented by 13 accessions of weedy S. halepense from Asia, Africa, and the USA, and 43 accessions of four wild races of S. bicolor subsp. verticilliflorum from Africa and the USA. Six cultivated types (Sorghum bicolor subsp. bicolor) including a commercial hybrid were selected at random to represent the five races. The accessions were chosen at random from the sorghum collection maintained at the International Crops Research Institute for the Semi-Arid Tropics (ICRISAT). The experiments were conducted during the 1998 and 1999 rainy seasons at ICRISAT, Patancheru, Andhra Pradesh, India.

The pathogen culture being maintained at ICRISAT was used in the screening. The pathogen was multiplied on an SDM susceptible cultivar, DMS 652 (IS 18433), grown in pots. The pots were maintained under greenhouse conditions at $28 \pm$ $2^{\circ} \mathrm{C}$. Seeds of wild and cultivated accessions were presoaked for $3 \mathrm{~h}$ and incubated at $25^{\circ} \mathrm{C}$. in the dark. Cultivated types germinated in $24 \mathrm{~h}$, while wild accessions took 2 to $3 \mathrm{~d}$. About 25 sprouted seeds of similar shoot and root lengths were transplanted in $15-\mathrm{cm}$-diam pots filled with a mixture of black soil (vertisol) and farm yard manure. Each accession was replicated twice. Seedlings at the coleoptile stage to one-leaf stage were inoculated with conidia (a suspension with $4 \times 10^{5}$ conidia $\mathrm{mL}^{-1}$ ) as described by Reddy et al. (1992). The susceptible, DMS 652 (IS 18433), and the resistant, QL 3 (IS 18757), cultivars were included as controls. After inoculation, the pots were incubated at $20^{\circ} \mathrm{C}$ and $95 \% \mathrm{RH}$ overnight, and then transferred to the greenhouse for disease development. Symptoms of systemic infection with clear chlorosis beginning at the base of the infected leaves started to appear 8 to $12 \mathrm{~d}$ after inoculation, and were clearly visible at about $14 \mathrm{~d}$. Counts of total plants and infected plants were recorded at 14 and $21 \mathrm{~d}$ after inoculation and percentage of diseased plants (disease incidence) was calculated. Accessions that remained disease free were reinoculated to ensure that these were not escapes.

The experiment was conducted in a completely randomized design. The check cultivars (controls) were replicated five times. The test entries differed in the two years. Percentage infection data were analyzed by the REML (Residual Maximum Likelihood) procedure that assumed a fully random model after angular transformation. The REML analysis was preferred since it can be used to provide unbiased and efficient estimates of treatment effects in unbalanced designs with more than one source of error. It also allows the assessment 
Table 1. Reaction of sorghum accessions to sorghum downy mildew (SDM) under greenhouse conditions.

\begin{tabular}{|c|c|c|c|c|}
\hline Section & Species/subspecies/race & Country of origin & $\begin{array}{c}\text { Accession } \\
\text { identity }\end{array}$ & $\begin{array}{c}\text { Mean SDM } \\
\text { incidence }(\%) \dagger\end{array}$ \\
\hline \multirow[t]{6}{*}{ Sorghum } & $\begin{array}{l}\text { S. bicolor subsp. bicolor: } \\
\text { race guinea } \\
\text { race kafir } \\
\text { race caudatum } \\
\text { race durra } \\
\text { race bicolor } \\
\text { hybrid }\end{array}$ & $\begin{array}{l}\text { Zimbabwe } \\
\text { USA } \\
\text { Sudan } \\
\text { India } \\
\text { USA }\end{array}$ & $\begin{array}{l}\text { IS } 14383 \\
\text { IS } 18773 \\
\text { IS } 21812 \\
\text { IS } 12868 \\
\text { IS } 611 \\
\text { CSH1 }\end{array}$ & $\begin{array}{l}0 \\
43.5 \\
71.8 \\
87.6 \\
90 \\
76.67\end{array}$ \\
\hline & S. bicolor subsp. verticilliflorum race aethiopicum & $\begin{array}{l}\text { Egypt } \\
\text { Cameroon } \\
\text { Sudan } \\
\text { Sudan } \\
\text { Sudan }\end{array}$ & $\begin{array}{l}\text { IS } \mathbf{1 8 8 2 1} \\
\text { IS } \mathbf{2 7 5 8 4} \\
\text { IS } \mathbf{1 8 8 1 9} \\
\text { IS } \mathbf{1 4 5 6 4} \\
\text { IS } \mathbf{1 4 5 6 7}\end{array}$ & $\begin{array}{c}0 \\
\mathbf{1 0 . 2} \\
\mathbf{3 0 . 7} \\
\mathbf{5 1 . 1} \\
\mathbf{7 5 . 5}\end{array}$ \\
\hline & S. bicolor subsp. verticilliflorum race arundinaceum & $\begin{array}{l}\text { USA } \\
\text { Ivory Coast } \\
\text { Malawi } \\
\text { Tanzania } \\
\text { Ivory Coast } \\
\text { Malawi } \\
\text { Nigeria } \\
\text { South Africa } \\
\text { USA } \\
\text { Angola } \\
\text { Angola } \\
\text { Angola } \\
\text { Burundi } \\
\text { Ghana }\end{array}$ & $\begin{array}{l}\text { IS } \mathbf{1 8 8 8 2} \\
\text { IS } \mathbf{1 8 8 2 6} \\
\text { IS } \mathbf{1 8 8 3 3} \\
\text { IS } \mathbf{1 8 8 3 0} \\
\text { IS } \mathbf{1 8 8 2 4} \\
\text { IS } 14359 \\
\text { IS } 18878 \\
\text { IS } 14301 \\
\text { IS } 18823 \\
\text { IS } 14216 \\
\text { IS } 14211 \\
\text { IS } \mathbf{2 0 8 8 9} \\
\text { IS } \mathbf{3 1 5 4 0} \\
\text { IS } \mathbf{1 8 8 8 3}\end{array}$ & \begin{tabular}{l|l}
\multicolumn{1}{l}{0} \\
3.1 \\
10.5 \\
13.4 \\
15.9 \\
20.5 \\
32.4 \\
45 \\
45.4 \\
50 \\
60.7 \\
69.5 \\
72.1 \\
72.2
\end{tabular} \\
\hline & S. bicolor subsp. verticilliflorum race verticilliflorum & $\begin{array}{l}\text { Ethiopia } \\
\text { Ethiopia } \\
\text { Kenya } \\
\text { South Africa } \\
\text { Malawi } \\
\text { South Africa } \\
\text { Chad } \\
\text { Sudan } \\
\text { Angola } \\
\text { Ethiopia } \\
\text { Kenya } \\
\text { Angola } \\
\text { Angola } \\
\text { USA } \\
\text { Ethiopia }\end{array}$ & $\begin{array}{l}\text { IS } 14583 \\
\text { IS } 18873 \\
\text { IS } 20995 \\
\text { IS } 14278 \\
\text { IS } 14357 \\
\text { IS } 14313 \\
\text { IS } 18802 \\
\text { IS } 18865 \\
\text { IS } 14219 \\
\text { IS } 14719 \\
\text { IS } 14571 \\
\text { IS } 14259 \\
\text { IS } 14234 \\
\text { IS } 18875 \\
\text { IS } 14717\end{array}$ & \begin{tabular}{|l|}
21.6 \\
31.3 \\
31.4 \\
34.4 \\
35.1 \\
65.7 \\
70.0 \\
72.5 \\
76.2 \\
77.3 \\
82.2 \\
84.4 \\
86.7 \\
90.6 \\
91.6
\end{tabular} \\
\hline & S. bicolor subsp. verticilliflorum race virgatum & $\begin{array}{l}\text { Egypt } \\
\text { Egypt } \\
\text { Somalia } \\
\text { Egypt } \\
\text { Egypt } \\
\text { Somalia } \\
\text { Sudan } \\
\text { Egypt } \\
\text { USA }\end{array}$ & $\begin{array}{l}\text { IS } 18813 \\
\text { IS } 18810 \\
\text { IS } 32754 \\
\text { IS } 18809 \\
\text { IS } 18808 \\
\text { IS } 32755 \\
\text { IS } 18817 \\
\text { IS } 18805 \\
\text { IS } 18803\end{array}$ & \begin{tabular}{|r|}
1.7 \\
1.8 \\
26.9 \\
30.7 \\
32.1 \\
48.2 \\
49.1 \\
65.6 \\
100.0
\end{tabular} \\
\hline & S. halepense & $\begin{array}{l}\text { Sudan } \\
\text { Angola } \\
\text { India } \\
\text { South Africa } \\
\text { USA } \\
\text { India } \\
\text { USA } \\
\text { India } \\
\text { Angola } \\
\text { India } \\
\text { Angola } \\
\text { USA } \\
\text { South Africa }\end{array}$ & $\begin{array}{l}\text { IS } 33712 \\
\text { IS } 14241 \\
\text { IS } 18849 \\
\text { IS } 18926 \\
\text { IS } 18897 \\
\text { IS } 18847 \\
\text { IS } 18899 \\
\text { IS } 18850 \\
\text { IS } 14212 \\
\text { IS } 18845 \\
\text { IS } 14263 \\
\text { IS } 18891 \\
\text { IS } 14299\end{array}$ & \begin{tabular}{|l|}
\multicolumn{1}{|l}{8} \\
8.8 \\
16.8 \\
18.8 \\
21.1 \\
28.5 \\
31.7 \\
32.2 \\
44.0 \\
49.5 \\
57.3 \\
62.4 \\
94.2 \\
\end{tabular} \\
\hline Chaetosorghum & S. macrospermum & Northern Territory, Australia & PQ24 & $\mathbf{0}$ \\
\hline Heterosoghum & S. laxiflorum & $\begin{array}{l}\text { Northern Territory, Australia } \\
\text { Northern Territory, Australia } \\
\text { Northern Territory, Australia } \\
\text { Northern Territory, Australia } \\
\text { Queensland, Australia } \\
\text { Queensland, Australia } \\
\text { Australia }\end{array}$ & $\begin{array}{l}\text { PQ155 } \\
\text { PQ156 } \\
\text { PQ157 } \\
\text { PQ158 } \\
\text { PQ159 } \\
\text { PQ162 } \\
\text { IS } 18958\end{array}$ & $\begin{array}{l}\mathbf{0} \\
\mathbf{0} \\
\mathbf{0} \\
\mathbf{0} \\
\mathbf{0} \\
\mathbf{0} \\
\mathbf{0}\end{array}$ \\
\hline
\end{tabular}

Continued next page. 
Table 1. Continued.

\begin{tabular}{|c|c|c|c|c|}
\hline Section & Species/subspecies/race & Country of origin & $\begin{array}{l}\text { Accession } \\
\text { identity }\end{array}$ & $\begin{array}{c}\text { Mean SDM } \\
\text { incidence }(\%) \dagger\end{array}$ \\
\hline Parasorghum & $\begin{array}{l}\text { S. australiense } \\
\text { S. brevicallosum } \\
\text { S. matarankense } \\
\text { S. nitidum } \\
\text { S. purpureosericeum subsp. deccanense } \\
\text { S. purpureosericeum subsp dimidiatum } \\
\text { S. timorense } \\
\text { S. versicolor }\end{array}$ & $\begin{array}{l}\text { Australia } \\
\text { Australia } \\
\text { Australia } \\
\text { Northern Territory, Australia } \\
\text { Australia } \\
\text { Northern Territory, Australia } \\
\text { Australia } \\
\text { Queensland, Australia } \\
\text { India } \\
\text { Tanzania } \\
\text { India } \\
\text { India } \\
\text { India } \\
\text { Sudan } \\
\text { Sudan } \\
\text { Northern Territory, Australia } \\
\text { Northern Territory, Australia } \\
\text { South Africa } \\
\text { Angola } \\
\text { South Africa } \\
\text { South Africa } \\
\text { Tanzania } \\
\text { Tanzania } \\
\text { Malawi } \\
\text { Tanzania } \\
\text { Tanzania } \\
\text { Tanzania } \\
\text { Tanzania }\end{array}$ & $\begin{array}{l}\text { IS } 18954 \\
\text { IS } 18955 \\
\text { IS } 18956 \\
\text { PQ2/1 } \\
\text { RN320 } \\
\text { PQ25 } \\
\text { RN341 } \\
\text { PQ22-1 } \\
\text { RN285 } \\
\text { IS } 18943 \\
\text { IS } 18947 \\
\text { IS } 22191 \\
\text { IS } 18951 \\
\text { IS } 18944 \\
\text { IS } 18945 \\
\text { PQ14-1 } \\
\text { PQ26-1 } \\
\text { IS } 18926 \\
\text { IS } 14262 \\
\text { IS } 14275 \\
\text { IS } 18940 \\
\text { IS } 18941 \\
\text { IS } 23177 \\
\text { IS } 18929 \\
\text { IS } 23147 \\
\text { IS } 23159 \\
\text { IS } 23175 \\
\text { IS } 18942\end{array}$ & $\begin{array}{l}\text { 0 } \\
\mathbf{0} \\
\mathbf{0} \\
\mathbf{0} \\
\mathbf{0} \\
\mathbf{0} \\
\mathbf{0} \\
\mathbf{0} \\
\mathbf{0} \\
\mathbf{0} \\
\mathbf{0} \\
\mathbf{0} \\
\mathbf{3 . 1} \\
\mathbf{0} \\
\mathbf{0} \\
\mathbf{0} \\
\mathbf{0} \\
\mathbf{0} \\
\mathbf{0} \\
\mathbf{0} \\
\mathbf{0} \\
\mathbf{0} \\
\mathbf{3 . 2} \\
\mathbf{0} \\
\mathbf{0} \\
\mathbf{0} \\
\mathbf{0} \\
\mathbf{0}\end{array}$ \\
\hline Stiposorghum & $\begin{array}{l} \\
\text { S. ecarinatum } \\
\text { S. extans } \\
\text { S. intrans } \\
\text { S. interjectum } \\
\text { S. } \text { stiposorghum }\end{array}$ & $\begin{array}{l}\text { Queensland, Australia } \\
\text { Queensland, Australia } \\
\text { Queensland, Australia } \\
\text { Queensland, Australia } \\
\text { Queensland, Australia } \\
\text { Queensland, Australia } \\
\text { Northern Territory, Australia } \\
\text { Northern Territory, Australia } \\
\text { Northern Territory, Australia } \\
\text { Australia } \\
\text { Western Australia, Australia }\end{array}$ & $\begin{array}{l}\text { PQ10 } \\
\text { PQ2 } \\
\text { PQ3 } \\
\text { PQ5 } \\
\text { PQ7 } \\
\text { PQ9 } \\
\text { PQ19 } \\
\text { PQ35 } \\
\text { PQ30 } \\
\text { PQ47 } \\
\text { PQ100 }\end{array}$ & $\begin{array}{l}\mathbf{0} \\
\mathbf{0} \\
\mathbf{0} \\
\mathbf{0} \\
\mathbf{0} \\
\mathbf{0} \\
\mathbf{0} \\
\mathbf{0} \\
\mathbf{0} \\
\mathbf{0} \\
\mathbf{0}\end{array}$ \\
\hline
\end{tabular}

$\dagger$ Mean SDM incidence on resistant and susceptible controls was 0 and $85 \%$, respectively; Mean over all the accessions was $25.89 \%$ : SE: \pm 2.59 .

of information over similar experiments conducted at different times or places. Assuming asymptotic normality, the ratio of the estimated variance component to its standard error was compared with $\mathrm{Z}$ (standard normal deviate) table values at the 5 and $1 \%$ levels and error probabilities to test statistical significance of the effect of the variance components. The predicted mean values obtained were retransformed by inverse angular transformation.

\section{RESULTS AND DISCUSSION}

Highly significant $(P<0.01$ level $)$ differences in resistance to downy mildew were observed among the 109 accessions (Table 1). No significant accession $\times$ year or year effects were found. Forty-five of the wild accessions belonging to sections heterosorghum, chaetosorghum, stiposorghum, and parasorghum remained downy mildew free. Whereas, two accessions of parasorghum, IS 18951 (S. purpureosericeum) and IS 23177 (S. versicolor), developed about $3 \%$ downy mildew. Among the wild and weedy types in section sorghum, three accessions, one each in races aethiopicum (IS 18821) and arundinaceum (IS 18882) and one accession of S. halepense (IS 33712) were free from downy mildew. Accessions of race verticilliflorum showed the highest susceptibility (mean disease incidence of $63.4 \%$ ), while those of race aethiopicum were less susceptible (mean downy mildew of $33 \%$ ). Range of disease incidence in different accessions of race virgatum varied from 1.7 to $100 \%$.

The six accessions of cultivated sorghum showed a high level of disease incidence (mean downy mildew of $62 \%$ ) ranging from 43.5 to $90 \%$, except IS 14383 . IS 14383, a cultivated guinea sorghum from Zimbabwe, remained downy mildew free in successive inoculation tests. However, when screened by the sandwich test, two of the 42 inoculated plants developed downy mildew but the seedlings subsequently recovered within $15 \mathrm{~d}$. This accession grew to a height of $2.25 \mathrm{~m}$ during the post rainy season at the ICRISAT center, flowered in $58 \mathrm{~d}$, and produced lustrous (shiny) grain.

A large proportion of wild and weedy accessions $(52 \%)$ remained either downy mildew free or developed less than $10 \%$ disease to the ICRISAT pathotype. These sorghums, particularly those belonging to parasorghum, heterosorghum, chaetosorghum, and stiposorghum possess rich sources of genetic resistance to downy mildew. However, there is a need to test these accessions to other populations of the pathogen (Craig and Frederiksen, 1980; Pawar et al., 1985) to identify sources with broad-spectrum resistance. Such a screening will also be useful in determining differential susceptibilities of different sorghum species as has already been reported (Bonman et al., 1983).

Freedom from downy mildew in all the accessions 
from Australia compared with large variations (0-100\% downy mildew) in the downy mildew reaction of accessions from other countries is of considerable interest. Since downy mildew on sorghum is not prevalent in Australia, barring a few reports of its occurrence in maize (Reddy, 1979), the resistance in these accessions appears to have evolved in the absence of the pathogen and plausibly occurs by the presence of secondary metabolites inimical to pathogen growth. However, these are not isolated instances since resistance has also been detected in a cultivated sorghum cultivar (QL3) from Australia (Williams et al., 1982). The resistance in QL 3 has been effective against 16 pathotypes of downy mildew (Pawar et al., 1985).

The resistant accessions among the wild races of section sorghum noted in this study are primarily from East Africa (Sudan and Egypt). IS 18882, the resistant arundinaceum, though listed in the records as being from USA, in all probability was also originally from Africa. The north-east quadrant of Africa being the center of domestication and primary center of diversity of cultivated sorghums, the region is likely to harbor diversity to disease resistance as has been demonstrated for other crops (Leppik, 1970).

With the availability of resistance in the wild and weedy types, it is important to determine the degree of diversity among the downy mildew resistance genes in different accessions from Australia and also from other parts of the world. This study could provide information on the uniqueness (or lack thereof) of resistance genes in wild and weedy sorghums. If these accessions possess different genes, then it makes a strong case to use particularly the cross-compatible types to produce cultivars with durable resistance for areas where downy mildew is a serious problem and breakdown of resistance occurs. This approach is likely to provide long-term control of this disease as has been shown in other instances (Goodman et al., 1987).

Development of downy mildew symptoms on the cultivated sorghum IS 14383 after forced inoculation (sandwich test) and its subsequent recovery is quite remarkable. This phenomenon of recovery resistance has been reported earlier in pearl millet (Pennisetum americanum L) and sorghum (Singh and King, 1988; Singh and de Milliano, 1989). While IS 14383 could be a valuable source of downy mildew resistance, its uniqueness needs to be characterized in terms of tangible metabolites, possibly the prevalence of phenolics. There is also a need to test its reaction to other pathotypes. The present study identifies many new sources of resistance to sor- ghum downy mildew from cross compatible species of Sorghum, which could be used to develop resistant cultivars. Recent advancements in genetic engineering offer a distinct possibility of utilizing genes from cross-incompatible species as well.

\section{ACKNOWLEDGMENTS}

The first author thanks the NBPGR (ICAR), New Delhi, India, for the financial support during the course of the research conducted as part of the Ph.D. program. The statistical discussions with Dr. S. Chandra (Senior Scientist, Statistics, ICRISAT) and technical assistance provided by Mr. Mohan Rao and Mr. Rajan are gratefully acknowledged.

\section{REFERENCES}

Bonman, J.M., Y. Paisooksantivatana, and P. Pitipornchai. 1983. Host range of Peronosclerospora sorghi in Thailand. Plant Dis. 67:630632.

Craig, J., and R.A. Frederiksen, 1980. Pathotypes of Peronosclerospora sorghi. Plant Dis. 64:778-779.

Craig J., and G.N. Odvody. 1992. Current status of sorghum downy mildew control. p. 213-217. In W.A.J. de Milliano et al. (ed.) Sorghum and millets diseases: A second world review. AP 502324 ICRISAT, Patancheru, India.

Frederiksen, R.A., A.J. Bockholt, L.E. Clark, J.W. Cosper, J. Craig, J.W. Johnson, B.L. Jones, P. Matocha, F.R. Miller, L. Reys, D.T. Rosenow, D. Tuleen, and H.J. Walker 1973. Sorghum downy mildew - a disease of maize and sorghum. Res. Monogr. 2. Texas Agric. Exp. Stn.

Goodman, R.M., H. Hauptli, A. Crossway, and V.C. Knauf. 1987. Gene transfer in crop improvement. Science 236:48-54.

Henzell, R.G., D.M. Persley, R.S. Greber, D.S. Fletcher, and L. van Slobbe. 1982. Development of grain sorghum lines with resistance to sugar cane mosaic and other sorghum diseases. Plant Dis. 66:900901.

Leppik, E.E., 1970. Gene centers of plants as sources of disease resistance. Annu. Rev. Phytopathol. 8:323-344.

Pawar, M.N., R.A. Frederiksen, L.K. Mughogho, and M.R. Bonde. 1985. Survey of the virulence of Peronosclerospora sorghi isolates from Ethiopia, Nigeria, Texas (USA), Honduras, Brazil and Argentina. Phytopathology 75:1374.

Reddy, B.V.S., L.K. Mughogho, Y.D. Narayana, K.D. Nicodemus, and J.W. Stenhouse. 1992. Inheritance pattern of downy mildew resistance in advanced generations of sorghum. Ann. Appl. Biol. 121:249-255.

Reddy, D.B. 1979. New records of pests and diseases in South East Asia and the Pacific Region. [Jan'76-Dec'77. Tech. Doc. FAO Pl Prot. Comm. For the SEA and Pacific Region (1978) No 113, 6pp] Rev. Plant Path 58:1220.

Shivana, H., and K.H. Anahosur. 1990. Breeding downy mildew resistant sorghum varieties. Ind. Phytopathol. 43:372-374.

Singh, S.D., and W.A.J. de Milliano. 1989. First report of recovery of Sorghum from downy mildew in Zimbabwe. Plant Dis. 73-1020.

Singh, S.D., and S.B. King. 1988. Recovery resistance to downy mildew in pearl millet. Plant Dis. 77:425-428.

Williams, R.J., S.R.S. Dange, L.K. Mughogho, and K.N Rao. 1982. Identification of QL-3 sorghum: A source of resistance to Peronosclerospora sorghi. Plant Dis. 66:807-809. 